\title{
ANALISA TINGKAT KESEHATAN BANK SYARIAH
}

\author{
Diana Marlyna ${ }^{1)}$, Mohan Aka Wirando ${ }^{2)}$ \\ ${ }^{1)}$ Fakultas Ekonomi dan Bisnis, Universitas Teknokrat Indonesia \\ ${ }^{2}$ Sistem Informasi, Universitas Teknokrat Indonesia \\ Jl. H.ZA Pagaralam, No 9-11, Labuhanratu,Bandarlampung \\ Email : dianamarlyna@gmail.com ${ }^{1)}$, mohanakaw@gmail.com ${ }^{2)}$
}

\begin{abstract}
Abstrak
Perbankan di Indonesia memiliki dua sistem yaitu perbankan dengan sistem konvensional dan perbankan dengan sistem syariah. Pentingnya perbankan bagi perekonomian, di Indonesia perbankan diatur dan diawasi oleh Bank Indonesia dan Otoritas Jasa Keuangan (OJK). BI dan OJK dapat berkoordinasi dalam pengaturan dan pengawasan perbankan (UU No 21, 2011, pasal 39). Penilaian kesehatan bagi perbankan syariah diatur dalam Peraturan Otoritas Jasa Keuangan (POJK) No.8/POJK.03/2014 yaitu penilaian dengan menggunakan indikator Profil Risiko (Risk Profile), Good Corporate Governance (GCG), Rentabilitas (Earning), dan Permodalan (Capital).

Penelitian ini menganalisis kesehatan Bank Central Asia Syariah, Bank Muamalat, Bank Negara Indonesia Syariah, Bank Rakyat Indonesia Syariah, dan Bank Syariah Bukopin dengan metode RGEC (Risk Profile, GCG, Earning, Capital), namun tidak menggunakan faktor GCG karena keterbatasan data yang harus diolah dalam faktor GCG meliputi data kuisioner terhadap pihak stakeholder bank. Secara umum kinerja keuangan bank syariah tahun 2012-2016 adalah sehat, bahkan beberapa sangat sehat. Untuk penelitian selanjutnya dapat mengikutsertakan factor Good Corporate Governance (GCG) dengan menyebarkan kuesioner.
\end{abstract}

\section{Pendahuluan}

Lembaga keuangan, khusunya perbankan memiliki peran yang sangat penting dalam perekonomian suatu negara. Peranan bank dalam negeri untuk memenuhi kebutuhan ekonomi dalam negeri seperti administrasi keuangan, pertukaran uang, pengawasan uang, dan perkreditan, sedangkan peranan luar negeri meliputi perputaran devisa dan hubungan moneter antar negara. Menurut Undang-undang Nomor 10 Tahun 1998 Pasal 1 Ayat 2 tentang perbankan, bank adalah badan usaha yang menghimpun dana dari masyarakat dalam bentuk simpanan dan menyalurkannya kepada masyarakat dalam bentuk kredit atau bentuk-bentuk lainnya dalam rangka meningkatkan taraf hidup rakyat banyak. Pentingnya perbankan bagi perekonomian, di Indonesia perbankan diatur dan diawasi oleh Bank Indonesia dan Otoritas Jasa Keuangan (OJK). BI dan OJK dapat berkoordinasi dalam pengaturan dan pengawasan perbankan (UU No 21, 2011, pasal 39).

Perbankan di Indonesia memiliki dua sistem yaitu perbankan dengan sistem konvensional dan perbankan dengan sistem syariah. Menurut Undang-undang Nomor 10 Tahun 1998 Pasal 1 Ayat 3, Bank Umum atau Konvensional adalah bank yang melaksanakan kegiatan usaha secara konvensional yang dalam kegiatannya memberikan jasa dalam lalu lintas pembayaran, sedangkan, Bank Syariah adalah bank yang menjalankan kegiatan usahanya berdasarkan prinsip syariah dan menurut jenisnya terdiri atas Bank Umum Syariah dan Bank Pembiayaan Rakyat Syariah (Undang-undang Nomor 21 Tahun 2008 Pasal 1 Ayat 7).

Perkembangan perbankan syariah pada era reformasi ditandai dengan disetujuinya Undang-Undang No. 10 Tahun 1998. Dalam undang-undang tersebut diatur dengan rinci landasan hukum serta jenis-jenis usaha yang dapat dioperasikan dan diimplementasikan oleh Bank Syariah. Undang-undang tersebut memberikan arahan bagi bank-bank konvensional untuk membuka cabang syariah atau bahkan mengkonversi diri secara total menjadi Bank Syariah. Peluang tersebut ternyata disambut antusias oleh masyarakat perbankan (Antonio, 2001).

Maraknya perbankan konvensional dan syariah, penting untuk memastikan kinerja keuangan perbankan selalu dalam kondisi yang baik. Kinerja keuangan Bank merujuk pada penilaian tingkat kesehatan Bank. Kesehatan Bank menjadi kepentingan semua pihak terkait, baik pemilik, pengelola (manajemen), dan masyarakat pengguna jasa bank (Peraturan Otoritas Jasa Keuangan Nomor 8/POJK.03/2014).

Penilaian kesehatan bagi perbankan syariah diatur dalam Peraturan Otoritas Jasa Keuangan (POJK) No.8/POJK.03/2014 yaitu penilaian dengan menggunakan indikator Profil Risiko (Risk Profile), Good Corporate Governance (GCG), Rentabilitas (Earning), dan Permodalan (Capital). Profil Risiko (Risk Profile) merupakan penilaian terhadap risiko inheren dan kualitas penerapan manajemen risiko dalam operasional Bank (PBI No.13/1/PBI/2011). Good Corporate Governance (GCG) merupakan penilaian terhadap manajemen Bank Umum Syariah (POJK No. 
8/POJK.03/2014 Rentabilitas (Earning) merupakan penilaian terhadap kinerja rentabilitas, sumber-sumber rentabilitas, dan kesinambungan rentabilitas (PBI No.13/1/PBI/2011). Permodalan (Capital) merupakan penilaian terhadap tingkat kecukupan permodalan dan pengelolaan permodalan (PBI No.13/1/PBI/2011). ).

Penelitian ini menganalisis kesehatan Bank Central Asia Syariah, Bank Muamalat, Bank Negara Indonesia Syariah, Bank Rakyat Indonesia Syariah, dan Bank Syariah Bukopin dengan metode RGEC (Risk Profile, $G C G$, Earning, Capital), namun tidak menggunakan faktor GCG karena keterbatasan data yang harus diolah dalam faktor GCG meliputi data kuisioner terhadap pihak stakeholder bank. Laporan keuangan diambil dari situs resmi masing-masing bank untuk periode 20122016.

Penelitian terdahulu yang dilakukan oleh Dian Masita Dewi (2016) yang berjudul “Kinerja Keuangan Bank Konvensional dan Bank Syariah Studi Kasus PT. Bank Negara Indonesia Tbk tahun 2010-2014" menghasilkan sebuah penelitian tentang perbandingan kinerja keuangan antara BNI dan BNI Syariah dengan melihat tingkat kesehatan kedua bank menggunakan metode RGEC dengan rasio LDR (Loan to Deposit Ratio), rasio NPL (Non Performing Loan), rasio ROA (Return on Asset), dan rasio CAR (Capital Adequacy Ratio). Hasil penelitian menyatakan bahwa Hasil penelitian menunjukkan bahwa terdapat perbedaan kinerja keuangan yang signifikan antara bank konvensional dan bank syariah selama periode 2010-2014. Secara umum, dalam hal likuiditas, profitabilitas, dan modal keuangan Bank Negara Indonesia kinerjanya lebih baik dari pada Bank Negara Indonesia Syariah. Bank Negara Indonesia Syariah hanya memiliki kualitas aset yang lebih baik dari Bank Negara Indonesia.

\section{Pembahasan}

\subsection{Analisis Laporan Keuangan Bank Central Asia Syariah}

Hasil analisis laporan keuangan Bank Central Asia Syariah dapat dilihat pada tabel 1 dibawah ini.

Tabel 1 Analisis Laporan Keuangan Bank Central Asia Syariah

\begin{tabular}{|c|c|c|c|c|c|}
\hline $\begin{array}{c}\text { Metode } \\
\text { RGEC }\end{array}$ & $\mathbf{2 0 1 2}$ & $\mathbf{2 0 1 3}$ & $\mathbf{2 0 1 4}$ & $\mathbf{2 0 1 5}$ & $\mathbf{2 0 1 6}$ \\
\hline NPF & $0,10 \%$ & $0,07 \%$ & $0,14 \%$ & $0,71 \%$ & $0,49 \%$ \\
\hline $\begin{array}{c}\text { Kriteria } \\
\text { NPF }\end{array}$ & $\begin{array}{c}\text { Sangat } \\
\text { Sehat }\end{array}$ & $\begin{array}{c}\text { Sangat } \\
\text { Sehat }\end{array}$ & $\begin{array}{c}\text { Sangat } \\
\text { Sehat }\end{array}$ & $\begin{array}{c}\text { Sangat } \\
\text { Sehat }\end{array}$ & $\begin{array}{c}\text { Sangat } \\
\text { Sehat }\end{array}$ \\
\hline FDR & $79,86 \%$ & $83,38 \%$ & $91,06 \%$ & $90,75 \%$ & $90,11 \%$ \\
\hline $\begin{array}{c}\text { Kriteria } \\
\text { FDR }\end{array}$ & Sehat & Sehat & $\begin{array}{c}\text { Cukup } \\
\text { Sehat }\end{array}$ & $\begin{array}{c}\text { Cukup } \\
\text { Sehat }\end{array}$ & $\begin{array}{c}\text { Cukup } \\
\text { Sehat }\end{array}$ \\
\hline
\end{tabular}

\begin{tabular}{|c|c|c|c|c|c|}
\hline ROA & $0,78 \%$ & $0,88 \%$ & $0,68 \%$ & $0,84 \%$ & $1,05 \%$ \\
\hline $\begin{array}{c}\text { Kriteria } \\
\text { ROA }\end{array}$ & $\begin{array}{c}\text { Kurang } \\
\text { Sehat }\end{array}$ & $\begin{array}{c}\text { Kurang } \\
\text { Sehat }\end{array}$ & $\begin{array}{c}\text { Tidak } \\
\text { Sehat }\end{array}$ & $\begin{array}{c}\text { Kurang } \\
\text { Sehat }\end{array}$ & $\begin{array}{c}\text { Cukup } \\
\text { Sehat }\end{array}$ \\
\hline BOPO & $84,93 \%$ & $80,23 \%$ & $82,18 \%$ & $91,26 \%$ & $88,84 \%$ \\
\hline $\begin{array}{c}\text { Kriteria } \\
\text { BOPO }\end{array}$ & $\begin{array}{c}\text { Sangat } \\
\text { Sehat }\end{array}$ & $\begin{array}{c}\text { Sangat } \\
\text { Sehat }\end{array}$ & $\begin{array}{c}\text { Sangat } \\
\text { Sehat }\end{array}$ & $\begin{array}{c}\text { Sangat } \\
\text { Sehat }\end{array}$ & $\begin{array}{c}\text { Sangat } \\
\text { Sehat }\end{array}$ \\
\hline CAR & $31,43 \%$ & $22,32 \%$ & $29,53 \%$ & $34,33 \%$ & $36,78 \%$ \\
\hline $\begin{array}{c}\text { Kriteria } \\
\text { CAR }\end{array}$ & $\begin{array}{c}\text { Sangat } \\
\text { Sehat }\end{array}$ & $\begin{array}{c}\text { Sangat } \\
\text { Sehat }\end{array}$ & $\begin{array}{c}\text { Sangat } \\
\text { Sehat }\end{array}$ & $\begin{array}{c}\text { Sangat } \\
\text { Sehat }\end{array}$ & $\begin{array}{c}\text { Sangat } \\
\text { Sehat }\end{array}$ \\
\hline
\end{tabular}

Sumber: Data Diolah (2018)

Dari tabel diatas dapat dijelaskan bahwa Non Performing Financing (NPF) Bank Central Asia Syariah pada tahun 2012-2016 dalam posisi sangat sehat karena nasabah memenuhi kewajibannya dalam membayar kredit atau pembiayaan yang telah dipinjam. Sehingga, kemungkinan kerugian bank sangat kecil berupa pembiayaan bermasalah seperti pembiayaan kurang lancar, diragukan, dan macet dapat diatasi.

Rasio Financing to Deposit Ratio (FDR) Bank Central Asia Syariah pada tahun 2012-2013 dalam kondisi sehat atau masih termasuk kategori standar ideal dari Bank Indonesia. Namun, 3 tahun terakhir pada tahun 20142016 mengalami penurunan masing - masing rasio FDR sebesar 91,06\%, 90,75\% dan $90,10 \%$ yang mencerminkan bahwa dana pihak ketiga yang dikumpulkan berupa giro, simpanan dan deposito tidak terlalu signifikan perbedaannya terhadap total pembiayaan yang semakin naik dari tahun ke tahun, dimana dalam posisi rasio FDR cukup sehat yang menjadi peringatan karena sudah melewati batas standar yang telah ditentukan oleh Bank Indonesia.

Rasio Return on Asset (ROA) Bank Central Asia Syariah mengalami kondisi yang kurang baik pada tahun 20122013 karena laba yang diperoleh lebih kecil dari total aset, bahkan pada tahun 2014 memasuki kategori tidak sehat yaitu $0,67 \%$, sedangkan standar untuk kategori sehat adalah 1,216\%. Namun, pada tahun 2015-2016 mengalami peningkatan walaupun tidak signifikan karena masih dibawah standar yang ditetapkan oleh Bank Indonesia.

Rasio Beban Operasional dan Pendapatan Operasional (BOPO) Bank Central Asia Syariah pada tahun 20122016 dalam kondisi sangat sehat, karena pendapatan operasional yang diperoleh lebih besar dari beban operasional.

Rasio Capital Adequacy Ratio (CAR) Bank Central Asia Syariah pada tahun 2012-2016 dalam kondisi sangat sehat, karena bank mampu memenuhi kecukupan modal untuk menunjang aktiva yang mengandung resiko. Standar CAR yang telah ditetapkan Bank Indonesia 
adalah 8\% sampai 9,5\%, sedangkan Bank Central Asia Syariah memiliki nilai CAR yang sangat tinggi sehingga memungkinkan untuk mengantisipasi dalam keadaan yang beresiko.

\subsection{Analisis Laporan Keuangan Bank Muamalat Indonesia}

Hasil analisis laporan keuangan Bank Muamalat Indonesia dapat dilihat pada tabel 2 dibawah ini.

Tabel 2 Analisis Laporan Keuangan Bank Muamalat Indonesia

\begin{tabular}{|c|c|c|c|c|c|}
\hline $\begin{array}{c}\text { Metode } \\
\text { RGEC }\end{array}$ & 2012 & 2013 & 2014 & 2015 & 2016 \\
\hline NPF & $2,09 \%$ & $1,35 \%$ & $6,52 \%$ & $7,11 \%$ & $3,82 \%$ \\
\hline $\begin{array}{c}\text { Kriteria } \\
\text { NPF }\end{array}$ & Sehat & $\begin{array}{c}\text { Sangat } \\
\text { Sehat }\end{array}$ & $\begin{array}{c}\text { Cukup } \\
\text { Sehat }\end{array}$ & $\begin{array}{c}\text { Cukup } \\
\text { Sehat }\end{array}$ & Sehat \\
\hline FDR & $94,15 \%$ & $100,20 \%$ & $84,14 \%$ & $90,37 \%$ & $95,44 \%$ \\
\hline $\begin{array}{c}\text { Kriteria } \\
\text { FDR }\end{array}$ & $\begin{array}{l}\text { Cukup } \\
\text { Sehat }\end{array}$ & $\begin{array}{c}\text { Kurang } \\
\text { Sehat }\end{array}$ & Sehat & $\begin{array}{l}\text { Cukup } \\
\text { Sehat }\end{array}$ & $\begin{array}{c}\text { Cukup } \\
\text { Sehat }\end{array}$ \\
\hline ROA & $1,35 \%$ & $1,31 \%$ & $0,17 \%$ & $0,18 \%$ & $0,21 \%$ \\
\hline $\begin{array}{c}\text { Kriteria } \\
\text { ROA }\end{array}$ & Sehat & Sehat & $\begin{array}{l}\text { Tidak } \\
\text { Sehat } \\
\end{array}$ & $\begin{array}{l}\text { Tidak } \\
\text { Sehat }\end{array}$ & $\begin{array}{l}\text { Tidak } \\
\text { Sehat }\end{array}$ \\
\hline BOPO & $84,45 \%$ & $93,86 \%$ & $97,27 \%$ & $97,28 \%$ & $98,35 \%$ \\
\hline $\begin{array}{c}\text { Kriteria } \\
\text { BOPO }\end{array}$ & $\begin{array}{c}\text { Sangat } \\
\text { Sehat }\end{array}$ & $\begin{array}{l}\text { Sangat } \\
\text { Sehat }\end{array}$ & $\begin{array}{l}\text { Tidak } \\
\text { Sehat }\end{array}$ & $\begin{array}{l}\text { Tidak } \\
\text { Sehat }\end{array}$ & $\begin{array}{l}\text { Tidak } \\
\text { Sehat }\end{array}$ \\
\hline CAR & $11,57 \%$ & $14,05 \%$ & $13,91 \%$ & $12 \%$ & $12,74 \%$ \\
\hline $\begin{array}{c}\text { Kriteria } \\
\text { CAR }\end{array}$ & $\begin{array}{c}\text { Sangat } \\
\text { Sehat }\end{array}$ & $\begin{array}{c}\text { Sangat } \\
\text { Sehat }\end{array}$ & $\begin{array}{c}\text { Sangat } \\
\text { Sehat }\end{array}$ & $\begin{array}{l}\text { Sangat } \\
\text { Sehat }\end{array}$ & $\begin{array}{c}\text { Sangat } \\
\text { Sehat }\end{array}$ \\
\hline
\end{tabular}

Sumber: Data Diolah (2018)

Dari tabel diatas dapat dijelaskan bahwa Non Performing Financing (NPF) Bank Muamalat Indonesia pada tahun 2012 dalam kondisi sehat dan mengalami peningkatan ditahun 2013 menjadi sangat sehat dikarenakan pembiayaan bermasalah yang dialami oleh bank menurun 17,46\%. Tetapi, ditahun 2014-2015 Bank Muamalat Indonesia mengalami penurunan yang berakibat kondisi kesehatan bank menjadi cukup sehat karena kredit bermasalah dan total kredit yang tinggi. Pada tahun 2016, Bank Muamalat Indonesia mengalami peningkatan kembali karena pembiayaan bermasalah menurun $47,30 \%$ dari tahun sebelumnya.

Rasio Financing to Deposit Ratio (FDR) Bank Muamalat Indonesia pada tahun 2012 dalam kondisi cukup sehat, karena dana pihak ketiga yang dikumpulkan oleh Bank Muamalat Indonesia cukup tinggi dari total kredit sebesar 5,85\%. Pada tahun 2013, kondisi bank mengalami penurunan dari tahun sebelumnya, karena total pembiayaan atau kredit lebih tinggi dari dana pihak ketiga yang dikumpulkan dari tahun sebelumnya yang mengakibatkan rasio FDR menjadi kurang sehat. Pada tahun 2014, rasio FDR mengalami peningkatan sebesar $22,52 \%$ dari dana pihak ketiga tahun sebelumnya. Hal ini mengakibatkan kondisi bank menjadi sehat dari segi rasio FDR. Tetapi, pada tahun 2015-2016 kinerja bank dari segi rasio FDR kembali menurun menjadi kategori cukup sehat, karena dana pihak ketiga yang dikumpulkan menurun $11,96 \%$ dan $18,13 \%$ dari tahun 2014 .

Rasio Return on Assets (ROA) Bank Muamalat Indonesia pada tahun 2012-2013 dalam kondisi sehat, karena laba yang diperoleh $1,34 \%$ dan $1,31 \%$ termasuk standar ideal yang ditetapkan oleh Bank Indonesia. Namun, pada tahun 2014-2016 kondisi bank mengalami penurunan yang signifikan menjadi tidak sehat, karena penurunan laba sangat drastis yang diperoleh dari tahun - tahun sebelumnya.

Rasio Beban Operasional dan Pendapatan Operasional (BOPO) Bank Muamalat Indonesia pada tahun 20122013 dalam kondisi sangat sehat karena total pendapatan yang dicapai melebihi dari total beban. Tetapi, pada tahun 2014-2016 mengalami penurunan sangat signifikan karena 3 tahun berturut-turut yaitu 97,26\%, 97,28\% dan 98,35\% yang mengakibatkan kondisi keuangan mengalami tidak sehat.

Rasio Capital Adequacy Ratio (CAR) Bank Muamalat Indonesia pada tahun 2012-2016 dalam kondisi sangat sehat, karena rasio CAR berada pada lebih dari standar yang telah ditetapkan oleh Bank Indonesia. Sehingga, bank mampu memenuhi kecukupan modal untuk menunjang aktiva yang mengandung resiko. Meskipun ditiap tahunnya memiliki dinamika naik turun, tetapi masih dalam standar ideal yang telah ditetapkan.

\subsection{Analisis Laporan Keuangan Bank Negara Indonesia Syariah}

Berikut hasil analisis laporan keuangan Bank Negara Indonesia Syariah dapat dilihat pada tabel 3 dibawah ini.

Tabel 3. Analisis Laporan Keuangan Bank Negara Indonesia Syariah

\begin{tabular}{|c|c|c|c|c|c|}
\hline $\begin{array}{c}\text { Metode } \\
\text { RGEC }\end{array}$ & 2012 & 2013 & 2014 & 2015 & 2016 \\
\hline NPF & $2,02 \%$ & $1,84 \%$ & $1,89 \%$ & $2,51 \%$ & $2,94 \%$ \\
\hline $\begin{array}{c}\text { Kriteria } \\
\text { NPF }\end{array}$ & Sehat & $\begin{array}{l}\text { Sangat } \\
\text { Sehat }\end{array}$ & $\begin{array}{l}\text { Sangat } \\
\text { Sehat }\end{array}$ & Sehat & Sehat \\
\hline FDR & $\begin{array}{c}84,98 \\
\%\end{array}$ & $\begin{array}{c}97,86 \\
\% \\
\end{array}$ & $\begin{array}{c}92,58 \\
\% \\
\end{array}$ & $\begin{array}{c}91,94 \\
\% \\
\end{array}$ & $\begin{array}{c}84,57 \\
\%\end{array}$ \\
\hline $\begin{array}{c}\text { Kriteria } \\
\text { FDR }\end{array}$ & Sehat & $\begin{array}{c}\text { Cukup } \\
\text { Sehat }\end{array}$ & $\begin{array}{l}\text { Cukup } \\
\text { Sehat }\end{array}$ & $\begin{array}{l}\text { Cukup } \\
\text { Sehat }\end{array}$ & Sehat \\
\hline ROA & $1,43 \%$ & $1,41 \%$ & $1,29 \%$ & $1,44 \%$ & $1,45 \%$ \\
\hline $\begin{array}{c}\text { Kriteria } \\
\text { ROA }\end{array}$ & Sehat & Sehat & Sehat & Sehat & Sehat \\
\hline ВOPO & $\begin{array}{c}83,65 \\
\%\end{array}$ & $\begin{array}{c}88,17 \\
\%\end{array}$ & $\begin{array}{c}89,51 \\
\%\end{array}$ & $88,7 \%$ & $\begin{array}{c}87,29 \\
\%\end{array}$ \\
\hline $\begin{array}{c}\text { Kriteria } \\
\text { BOPO }\end{array}$ & $\begin{array}{c}\text { Sangat } \\
\text { Sehat }\end{array}$ & $\begin{array}{c}\text { Sangat } \\
\text { Sehat }\end{array}$ & $\begin{array}{c}\text { Sangat } \\
\text { Sehat }\end{array}$ & $\begin{array}{c}\text { Sangat } \\
\text { Sehat }\end{array}$ & $\begin{array}{c}\text { Sangat } \\
\text { Sehat }\end{array}$ \\
\hline CAR & $\begin{array}{c}19,07 \\
\% \\
\end{array}$ & $\begin{array}{c}16,22 \\
\% \\
\end{array}$ & $\begin{array}{c}18,42 \\
\%\end{array}$ & $\begin{array}{c}18,16 \\
\%\end{array}$ & $\begin{array}{c}14,92 \\
\% \\
\end{array}$ \\
\hline $\begin{array}{c}\text { Kriteria } \\
\text { CAR }\end{array}$ & $\begin{array}{c}\text { Sangat } \\
\text { Sehat }\end{array}$ & $\begin{array}{c}\text { Sangat } \\
\text { Sehat }\end{array}$ & $\begin{array}{l}\text { Sangat } \\
\text { Sehat }\end{array}$ & $\begin{array}{c}\text { Sangat } \\
\text { Sehat }\end{array}$ & $\begin{array}{c}\text { Sangat } \\
\text { Sehat }\end{array}$ \\
\hline
\end{tabular}

Sumber: Data Diolah (2018) 
Dari tabel diatas dapat dijelaskan bahwa Non Performing Financing (NPF) Bank Negara Indonesia Syariah pada tahun 2012 dalam kondisi sehat, karena rasio NPF sebesar 2,01\%. Hal ini masih dikategorikan normal karena standar ideal yang ditetapkan adalah kurang dari 5\%. Terjadi peningkatan kriteria pada tahun 2013-2014 menjadi sangat sehat, karena pembiayaan bermasalah masih dapat dikendalikan walaupun total pembiayaan naik setiap tahunnya. Pada tahun 2015-2016 NPF Bank Negara Indonesia Syariah secara berturut-turut sebesar $2,51 \%$ dan $2,93 \%$ artinya dalam kondisi sehat yang mengakibatkan penurunan dari tahun sebelumnya walau tidak melewati batas yang telah ditentukan.

Rasio Financing to Deposit Ratio (FDR) Bank Negara Indonesia Syariah pada tahun 2012 dalam kondisi sehat sebesar $84,97 \%$, tetapi pada 3 tahun selanjutnya mengalami penurunan menjadi cukup sehat, karena total pembiayaan yang dikeluarkan mendekati dengan dana pihak ketiga yang dikumpulkan. Namun, pada tahun 2016 naik menjadi kondisi sehat, karena dana pihak ketiga yang dikumpulkan lebih banyak dari total pembiayaan yang dikeluarkan sebesar $15,42 \%$.

Rasio Return on Assets (ROA) Bank Negara Indonesia Syariah menghasilkan predikat yang baik karena dapat mampu mempertahankan atau meningkatkan laba yang diperoleh dari periode satu ke periode lain. Meskipun umumnya berbeda selisih angka yang sedikit, tetapi bank mampu menjaga kekonsistenan predikat sehat selama 5 tahun.

Rasio Beban Operasional dan Pendapatan Operasional (BOPO) Bank Negara Indonesia Syariah selama 5 tahun periode menghasilkan predikat yang sangat sehat, artinya bank konsisten dalam memperoleh total pendapatan yang diperoleh dan lebih banyak dari total beban yang digunakan.

Rasio Capital Adequacy Ratio (CAR) Bank Negara Indonesia Syariah selama 5 tahun periode yaitu 20122016 menghasilkan predikat yang sangat sehat, artinya bank mampu mengendalikan aktiva yang mengandung risiko pada periode tersebut. Sehingga, bank dapat melakukan antisipasi terhadap risiko - risiko yang akan terjadi.

\subsection{Analisis Laporan Keuangan Bank Rakyat Indonesia Syariah}

Hasil analisis laporan keuangan Bank Rakyat Indonesia Syariah dapat dilihat pada tabel 4 dibawah ini.

Tabel 4. Analisis Laporan Keuangan Bank Rakyat Indonesia Syariah

\begin{tabular}{|c|c|c|c|c|c|}
\hline $\begin{array}{c}\text { Metode } \\
\text { RGEC }\end{array}$ & $\mathbf{2 0 1 2}$ & $\mathbf{2 0 1 3}$ & $\mathbf{2 0 1 4}$ & $\mathbf{2 0 1 5}$ & $\mathbf{2 0 1 6}$ \\
\hline NPF & $2,97 \%$ & $4,03 \%$ & $4,46 \%$ & $4,82 \%$ & $4,57 \%$ \\
\hline $\begin{array}{c}\text { Kriteria } \\
\text { NPF }\end{array}$ & Sehat & Sehat & Sehat & Sehat & Sehat \\
\hline FDR & $95,44 \%$ & $102,70 \%$ & $93,90 \%$ & $84,79 \%$ & $81,25 \%$ \\
\hline
\end{tabular}

\begin{tabular}{|c|c|c|c|c|c|}
\hline $\begin{array}{c}\text { Kriteria } \\
\text { FDR }\end{array}$ & $\begin{array}{c}\text { Cukup } \\
\text { Sehat }\end{array}$ & $\begin{array}{c}\text { Kurang } \\
\text { Sehat }\end{array}$ & $\begin{array}{c}\text { Cukup } \\
\text { Sehat }\end{array}$ & Sehat & Sehat \\
\hline ROA & $1,09 \%$ & $1,16 \%$ & $0,08 \%$ & $0,76 \%$ & $0,92 \%$ \\
\hline $\begin{array}{c}\text { Kriteria } \\
\text { ROA }\end{array}$ & $\begin{array}{c}\text { Cukup } \\
\text { Sehat }\end{array}$ & $\begin{array}{c}\text { Cukup } \\
\text { Sehat }\end{array}$ & $\begin{array}{c}\text { Tidak } \\
\text { Sehat }\end{array}$ & $\begin{array}{c}\text { Tidak } \\
\text { Sehat }\end{array}$ & $\begin{array}{c}\text { Kurang } \\
\text { Sehat }\end{array}$ \\
\hline BOPO & $91,24 \%$ & $90,35 \%$ & $99,49 \%$ & $93,77 \%$ & $91,41 \%$ \\
\hline Kriteria & Sangat & Sangat & Tidak & Sangat & Sangat \\
BOPO & Sehat & Sehat & Sehat & Sehat & Sehat \\
\hline CAR & $11,34 \%$ & $14,49 \%$ & $12,89 \%$ & $13,93 \%$ & $20,63 \%$ \\
\hline Kriteria & Sangat & Sangat & Sangat & Sangat & Sangat \\
CAR & Sehat & Sehat & Sehat & Sehat & Sehat \\
\hline
\end{tabular}

Sumber: Data Diolah (2018)

Dari tabel diatas dapat dijelaskan bahwa Non Performing Financing (NPF) Bank Rakyat Indonesia Syariah selama 5 tahun periode dalam kondisi sehat, artinya bank dapat konsisten dalam mengendalikan pembiayaan bermasalah seperti pembiayaan kurang lancar, diragukan, macet. Jika dilihat dari persentase dari tahun 2012-2016 NPF Bank Rakyat Indonesia Syariah mengalami penaikan artinya semakin banyak pembiayaan bermasalah yang dialami oleh bank, tetapi bank masih dalam kondisi predikat sehat atau masih dalam dibawah standar yang telah ditetapkan.

Rasio Financing to Deposit Ratio (FDR) Bank Rakyat Indonesia Syariah pada tahun 2012 sebesar 95,34\% yang artinya dalam kondisi cukup sehat, karena dana pihak ketiga yang dikumpulkan oleh bank hanya melebihi $4,56 \%$ dari total pembiayaan. Pada tahun 2013, NPF Bank Rakyat Indonesia Syariah mengalami penurunan predikat menjadi kurang sehat, karena dana pihak ketiga yang dikumpulkan lebih sedikit daripada total pembiayaan. Pada tahun 2014-2016, NPF Bank Rakyat Indonesia Syariah berangsur-angsur mengalami peningkatan secara berurut sebesar 93,89\%, 84,79\%, dan $81,24 \%$ sehingga memperoleh predikat cukup sehat, sehat dan sehat.

Rasio Return on Assets (ROA) Bank Rakyat Indonesia Syariah mengalami kondisi yang kurang baik, pada tahun 2012-2013 memperoleh predikat cukup sehat yaitu sebesar $1,09 \%$ dan 1,16\%. Pada tahun 2014-2015 mengalami penurunan signifikan mengenai penurunan laba dan semakin meningkatnya rata total aset. Pada tahun 2016, ROA Bank Rakyat Indonesia Syariah sebesar $0,91 \%$ artinya mengalami kondisi yang kurang sehat disebabkan laba hanya meningkat sedikit dari tahun sebelumnya sedangkan rata total aset mengalami peningkatan yang signifikan dari tahun sebelumnya.

Rasio Beban Operasional dan Pendapatan Operasional (BOPO) Bank Rakyat Indonesia Syariah pada tahun 2012-2013 dalam kondisi sangat sehat. Karena total pendapatan operasional yang dicapai lebih besar dari total beban operasional. Namun, pada tahun 2014 mengalami penurunan yang sangat signifikan sebesar 99,48\% yang menjadi predikat bank tidak sehat, karena total pendapatan yang didapat pada periode ini lebih tinggi $0,5 \%$ dari total beban. Tetapi, pada tahun 2015- 
2016 Bank Rakyat Indonesia Syariah dapat meningkatkan BOPO secara signifikan menjadi predikat sangat sehat, karena total pendapatan yang diraih selama 2 tahun terakhir kembali stabil atau lebih tinggi dari total beban sedangkan rasio Capital Adequacy Ratio (CAR) Bank Rakyat Indonesia Syariah selama 5 tahun periode meraih predikat sangat sehat, artinya bank memiliki kemampuan dalam menyediakan dana yang digunakan untuk mengatasi kemungkinan risiko kerugian.

\subsection{Analisis Laporan Keuangan Bank Syariah Bukopin}

Hasil analisis laporan keuangan Bank Syariah Bukopin dapat dilihat pada tabel 5 dibawah ini.

Tabel 5. Analisis Laporan Keuangan Bank Syariah Bukopin

\begin{tabular}{|c|c|c|c|c|c|}
\hline $\begin{array}{c}\text { Metode } \\
\text { RGEC }\end{array}$ & $\mathbf{2 0 1 2}$ & $\mathbf{2 0 1 3}$ & $\mathbf{2 0 1 4}$ & $\mathbf{2 0 1 5}$ & $\mathbf{2 0 1 6}$ \\
\hline NPF & $4,56 \%$ & $4,27 \%$ & $4,04 \%$ & $2,97 \%$ & $3,15 \%$ \\
\hline $\begin{array}{c}\text { Kriteria } \\
\text { NPF }\end{array}$ & Sehat & Sehat & Sehat & Sehat & Sehat \\
\hline FDR & $92,32 \%$ & $100,28 \%$ & $92,89 \%$ & $90,56 \%$ & $88,18 \%$ \\
\hline $\begin{array}{c}\text { Kriteria } \\
\text { FDR }\end{array}$ & $\begin{array}{c}\text { Cukup } \\
\text { Sehat }\end{array}$ & $\begin{array}{c}\text { Kurang } \\
\text { Sehat }\end{array}$ & $\begin{array}{c}\text { Cukup } \\
\text { Sehat }\end{array}$ & $\begin{array}{c}\text { Cukup } \\
\text { Sehat }\end{array}$ & $\begin{array}{c}\text { Cukup } \\
\text { Sehat }\end{array}$ \\
\hline ROA & $0,76 \%$ & $0,68 \%$ & $0,25 \%$ & $0,73 \%$ & $0,73 \%$ \\
\hline $\begin{array}{c}\text { Kriteria } \\
\text { ROA }\end{array}$ & $\begin{array}{c}\text { Tidak } \\
\text { Sehat }\end{array}$ & $\begin{array}{c}\text { Tidak } \\
\text { Sehat }\end{array}$ & $\begin{array}{c}\text { Tidak } \\
\text { Sehat }\end{array}$ & $\begin{array}{c}\text { Tidak } \\
\text { Sehat }\end{array}$ & $\begin{array}{c}\text { Tidak } \\
\text { Sehat }\end{array}$ \\
\hline BOPO & $91,61 \%$ & $92,02 \%$ & $96,81 \%$ & $91,92 \%$ & $92,10 \%$ \\
\hline $\begin{array}{c}\text { Kriteria } \\
\text { BOPO }\end{array}$ & Sehat & Sehat & $\begin{array}{c}\text { Kurang } \\
\text { Sehat }\end{array}$ & Sehat & Sehat \\
\hline CAR & $12,77 \%$ & $11,08 \%$ & $14,78 \%$ & $16,30 \%$ & $16,99 \%$ \\
\hline $\begin{array}{c}\text { Kriteria } \\
\text { CAR }\end{array}$ & $\begin{array}{c}\text { Sangat } \\
\text { Sehat }\end{array}$ & $\begin{array}{c}\text { Sangat } \\
\text { Sehat }\end{array}$ & $\begin{array}{c}\text { Sangat } \\
\text { Sehat }\end{array}$ & $\begin{array}{c}\text { Sangat } \\
\text { Sehat }\end{array}$ & $\begin{array}{c}\text { Sangat } \\
\text { Sehat }\end{array}$ \\
\hline
\end{tabular}

Sumber: Data Diolah (2018) peningkatan menjadi cukup sehat dilihat dari persentase yang semakin membaik yaitu $92,88 \%, 90,55 \%$, dan $88,18 \%$.

Rasio Return on Assets (ROA) Bank Syariah Bukopin selama 5 tahun periode yaitu 2012-2016 dalam kondisi yang tidak sehat, dikarenakan laba (sebelum pajak) yang didapat oleh bank selama 5 tahun belum meraih keuntungan yang tinggi, tetapi total aset yang digunakan naik setiap tahunnya.

Rasio Beban Operasional dan Pendapatan Operasional (BOPO) Bank Syariah Bukopin pada tahun 2012-2013 dalam kondisi sangat sehat, karena pendapatan yang didapat oleh bank lebih tinggi dari beban yang dikeluarkan. Namun, pada tahun 2014 mengalami penurunan yang signifikan menjadi predikat kurang sehat karena pendapatan yang dicapai pada periode ini hanya dapat memberikan keuntungan $3,18 \%$. Tetapi, pada tahun 2015-2016 kondisi BOPO bank meningkat signifikan dan meraih predikat sangat sehat.

Rasio Capital Adequacy Ratio (CAR) Bank Syariah Bukopin selama 5 tahun periode yaitu 2012-2016 menghasilkan predikat yang sangat sehat, artinya bank mampu mengendalikan aktiva yang mengandung risiko kerugian pada periode tersebut. Sehingga, bank dapat melakukan antisipasi terhadap risiko - risiko yang akan terjadi.

\subsection{Analisis Laporan Keuangan Bank Syariah Mandiri}

Hasil analisis laporan keuangan Bank Syariah Mandiri dapat dilihat pada tabel 6 dibawah ini.

Tabel 5.6 Analisis Laporan Keuangan Bank Syariah Mandiri

Dari tabel diatas dapat dijelaskan bahwa Non Performing Financing (NPF) Bank Syariah Bukopin dalam 5 tahun periode konsisten mendapatkan predikat sehat, artinya bank dapat mengendalikan pembiayaan bermasalah seperti pembiayaan kurang lancar, diragukan, dan macet. Jika dilihat dari persentase dari tahun 2012-2016 NPF Bank Syariah Bukopin mengalami kinerja yang baik karena NPF yang dialami menurun disetiap tahun nya artinya semakin baik, tetapi bank masih dalam kondisi predikat sehat atau masih dalam dibawah standar yang telah ditetapkan.

Rasio Financing to Deposit Ratio (FDR) Bank Syariah Bukopin sebesar 92,31\% pada tahun 2012 artinya dalam kondisi cukup sehat, sehingga kemampuan bank dalam memenuhi kewajiban jangka pendeknya dapat diartikan dalam keadaan yang cukup baik. Namun, mengalami penurunan pada tahun 2013 menjadi 100, 27\% sehingga meraih predikat kurang sehat disebabkan total pembiayaan lebih tinggi dari dana yang dikumpulkan dari pihak ketiga. Pada tahun 2014-2016 mengalami

\begin{tabular}{|c|c|c|c|c|c|}
\hline $\begin{array}{c}\text { Metode } \\
\text { RGEC }\end{array}$ & 2012 & 2013 & 2014 & 2015 & 2016 \\
\hline NPF & $2,82 \%$ & $4,32 \%$ & $6,84 \%$ & $6,06 \%$ & $4,92 \%$ \\
\hline $\begin{array}{c}\text { Kriteria } \\
\text { NPF }\end{array}$ & Sehat & Sehat & $\begin{array}{c}\text { Cukup } \\
\text { Sehat }\end{array}$ & $\begin{array}{c}\text { Cukup } \\
\text { Sehat }\end{array}$ & Sehat \\
\hline FDR & $94,4 \%$ & $89,37 \%$ & $82,13 \%$ & $82,25 \%$ & $79,45 \%$ \\
\hline $\begin{array}{c}\text { Kriteria } \\
\text { FDR }\end{array}$ & $\begin{array}{l}\text { Cukup } \\
\text { Sehat }\end{array}$ & $\begin{array}{c}\text { Cukup } \\
\text { Sehat }\end{array}$ & Sehat & Sehat & Sehat \\
\hline ROA & $2,13 \%$ & $1,50 \%$ & $0,17 \%$ & $0,54 \%$ & $0,58 \%$ \\
\hline $\begin{array}{c}\text { Kriteria } \\
\text { ROA }\end{array}$ & $\begin{array}{c}\text { Sangat } \\
\text { Sehat }\end{array}$ & $\begin{array}{c}\text { Sangat } \\
\text { Sehat }\end{array}$ & $\begin{array}{l}\text { Tidak } \\
\text { Sehat }\end{array}$ & $\begin{array}{l}\text { Tidak } \\
\text { Sehat }\end{array}$ & $\begin{array}{l}\text { Tidak } \\
\text { Sehat }\end{array}$ \\
\hline BOPO & $79,81 \%$ & $77,18 \%$ & $85,1 \%$ & $94,64 \%$ & $93,95 \%$ \\
\hline $\begin{array}{c}\text { Kriteria } \\
\text { BOPO }\end{array}$ & $\begin{array}{c}\text { Sangat } \\
\text { Sehat }\end{array}$ & $\begin{array}{c}\text { Sangat } \\
\text { Sehat }\end{array}$ & $\begin{array}{c}\text { Sangat } \\
\text { Sehat }\end{array}$ & Sehat & $\begin{array}{c}\text { Sangat } \\
\text { Sehat }\end{array}$ \\
\hline CAR & $13,82 \%$ & $14,1 \%$ & $14,76 \%$ & $12,85 \%$ & $14,01 \%$ \\
\hline $\begin{array}{c}\text { Kriteria } \\
\text { CAR }\end{array}$ & $\begin{array}{c}\text { Sangat } \\
\text { Sehat }\end{array}$ & $\begin{array}{c}\text { Sangat } \\
\text { Sehat }\end{array}$ & $\begin{array}{c}\text { Sangat } \\
\text { Sehat }\end{array}$ & $\begin{array}{c}\text { Sangat } \\
\text { Sehat }\end{array}$ & $\begin{array}{c}\text { Sangat } \\
\text { Sehat }\end{array}$ \\
\hline
\end{tabular}

Sumber: Data Diolah (2018)

Dari tabel diatas dapat dijelaskan bahwa Non Performing Financing (NPF) Bank Syariah Mandiri pada tahun 
2012-2013 dalam kondisi sehat, artinya pembiayaan bermasalah berupa pinjaman oleh peminjam dapat dikendalikan dengan baik sehingga meminimalisir terjadinya risiko kredit. Tetapi, pada tahun 2014-2015 bank mengalami penurunan satu tingkat menjadi kondisi cukup sehat, karena pembiayaan bermasalah semakin naik di 2 periode ini. Pada tahun 2016, rasio NPF Bank Syariah Mandiri meraih predikat sehat kembali karena pembiayaan bermasalah menurun dari tahun sebelumnya.

Rasio Financing to Deposit Ratio (FDR) Bank Syariah Mandiri pada tahun 2012-2013 dalam kondisi cukup sehat, artinya bank dalam memenuhi kewajiban jangka pendeknya dan mengumpulkan dana pihak ketiga dalam kategori cukup baik. Pada tahun 2014-2016, rasio FDR naik satu tingkat menjadi kriteria yang sehat karena total dana pihak ketiga yang dikumpulkan naik signifikan dari tahun - tahun sebelumnya.

Rasio Return on Assets (ROA) Bank Syariah Mandiri pada tahun 2012-2013 dalam kondisi sangat sehat, artinya laba (sebelum pajak) yang didapat pada 2 periode ini menghasilkan laba yang tinggi. Tetapi, pada periode 2014-2016 mengalami penurunan signifikan sehingga memperoleh predikat tidak sehat, dikarenakan laba yang dicapai pada 3 periode ini tidak sebanding dengan total aset yang dimiliki, bahkan pada 2014 Bank Syariah Mandiri mengalami kerugian.

Rasio Beban Operasional dan Pendapatan Operasional (BOPO) Bank Syariah Mandiri pada tahun 2012-2014 berturut - turut sebesar 79,80\%, 77,18\% dan $85,09 \%$ meraih predikat sangat sehat, artinya kemampuan bank dalam mencapai pendapatan dan mengeluarkan biaya untuk beban terkendali sangat baik. Tetapi, pada tahun 2015 rasio BOPO Bank Syariah Mandiri sebesar 94,63\% sehingga mengalami penurunan satu tingkat menjadi kriteria sehat, namun masih dalam standar yang ditetapkan. Pada tahun 2016 rasio BOPO naik satu tingkat kembali meraih predikat sangat sehat, karena pendapatan yang dicapai lebih tinggi dari beban yang dikeluarkan.

Rasio Capital Adequacy Ratio (CAR) Bank Syariah Mandiri selama 5 tahun periode meraih predikat sangat sehat, artinya bank mampu mengendalikan aktiva dan dapat mengantisipasi risiko kerugian yang akan terjadi dengan penggunaan modal yang dimiliki.

\section{Kesimpulan}

Kinerja keuangan Bank Umum Syariah dianalisis menggunakan metode RGEC meliputi rasio Non Performing Financing (NPF), Financing to Deposit Ratio (FDR), Return on Assets (ROA), Beban Operasional dan Pendapatan Operasional (BOPO), dan Capital Adequacy Ratio (CAR) dengan mengambil data dari laporan keuangan bank yang telah di upload pada website resmi bank syariah masing - masing secara rutin tiap tahunnya. Secara umum kinerja keuangan bank syariah tahun 2012-2016 adalah sehat, bahkan beberapa sangat sehat. Untuk penelitian selanjutnya dapat mengikutsertakan factor Good Corporate Governance (GCG) dengan menyebarkan kuesioner.

\section{Daftar Pustaka}

Bank Indonesia. 2011. Peraturan Bank Indonesia Nomor 13/1/PBI/2011 Tentang Tata Cara Penilaian Kesehatan Bank Umum.

Bank Indonesia. 2011. Surat Edaran Bank Indonesia No. 13/24/DPNP Tahun 2011 Tentang Penilaian Tingkat Kesehatan Bank Umum.

Dewi, Dian Masita. 2016. Kinerja Keuangan Bank Konvensional dan Bank Syariah Study pada PT Bank Negara Indonesia Tbk tahun 2010-2014. JUrnal ILMU SOSIAL DAN HUMANIORA, I(2), p192-202.

Otoritas Jasa Keuangan. 2014. Peraturan Otoritas Jasa Keuangan Nomor 8/POJK.03/2014 Tentang Penilaian Tingkat Kesehatan Bank Umum Syariah dan Unit Usaha Syariah.

Otoritas Jasa Keuangan. 2017. Statistik Perbankan Syariah November 2017.

Undang-undang Nomor 10 Tahun 1998 Tentang Perbankan Indonesia.

Undang-undang Nomor 21 Tahun 2008 Tentang Perbankan Syariah. 